\title{
Controversies in the Management of Clinical Stage I Nonseminomatous Germ Cell Testicular Cancer
}

\author{
Kontroverzie $v$ manažmente neseminomatóznych germinatívnych \\ nádorov testis $v$ I. klinickom štádiu
}

\author{
Ondrus D. ${ }^{1}$, Kajo K. ${ }^{2}$, Stastna V. ${ }^{3}$, Ondrusova M. ${ }^{4,5}$ \\ $11^{\text {st }}$ Department of Oncology, Comenius University Faculty of Medicine, St. Elisabeth Cancer Institute, Bratislava, Slovak Republic \\ ${ }^{2}$ Department of Pathology, Slovak Medical University, St. Elisabeth Cancer Institute, Bratislava, Slovak Republic \\ ${ }^{3}$ Department of Public Health, Faculty of Health Sciences and Social Work, Trnava University in Trnava, Slovak Republic \\ ${ }^{4}$ St. Elizabeth University of Health and Social Sciences, Bratislava, Slovak Republic \\ ${ }^{5}$ Cancer Research Institute, Slovak Academy of Sciences, Bratislava, Slovak Republic
}

\begin{abstract}
Summary
Surveillance after orchiectomy alone has become popular in the management of clinical stage I of nonseminomatous germ cell testicular tumors (CSI NSGCTT). Efforts to identify patients at high-risk of relapse led to a search for risk factors in CSI NSGCTT. The aim of the current study was to analyze long-term experiences with risk-adapted therapeutic approaches (active surveillance and adjuvant chemotherapy). From 1/1992 to 2/2015, a total of 454 CSI NSGCTT patients were included in the study and stratified into two groups according to risk-adapted therapeutic approaches. In Group A (low-risk CSI NSGCTT), which consisted of 287 patients who underwent surveillance, relapse occurred in $48(16.7 \%)$ patients with a median follow-up of 7.0 months. Six patients (2.1\%) of this group died with a median follow-up of 34.3 months. In Group B (high-risk CSI NSGCTT), which consisted of 167 patients who were treated with adjuvant chemotherapy, relapse occurred in two (1.2\%) patients with a median follow-up of 56.2 months. One patient $(0.6 \%)$ died 139.4 months following orchiectomy. Statistically significant difference in progression free survival between these two groups was found, but no significant difference in overall survival.
\end{abstract}

\section{Key words}

testicular cancer - surveillance - adjuvant chemotherapy - disease progression

\section{Súhrn}

Prísny dohlad po orchiektómii samotnej sa stal populárnym v manažmente neseminomatóznych germinatívnych nádorov testis $v$ I. klinickom štádiu (clinical stage I nonseminomatous germ cell testicular tumors - CSI NSGCTT). Úsilie identifikovat pacientov s vysokým rizikom progresie ochorenia viedlo k vyhladávaniu rizikových faktorov u CSI NSGCTT. Ciel'om súčasnej štúdie bolo analyzovat' dlhoročné skúsenosti s liečebnými postupmi založenými na prítomnosti rizikových faktorov (prísny dohl'ad a adjuvantná chemoterapia). V období 1/1992-2/2015 bolo celkovo 454 pacientov s CSI NSGCTT zaradených do štúdie. Stratifikovali sa do dvoch skupín podla použitých liečebných postupov v závislosti na prítomnosti rizikových faktorov. Skupina A (CSI NSGCTT s nízkym rizikom) pozostávala z 287 pacientov ktorí podstúpili prísny dohlad, progresia ochorenia sa zistila u $48(16,7 \%)$ pacientov po mediáne sledovania 7,0 mesiacov. Šest' pacientov $(2,1 \%)$ v tejto skupine zomrelo po mediáne sledovania 34,3 mesiacov. Skupina B (CSI NSGCTT s vysokým rizikom) pozostávala z 167 pacientov, ktorí boli dostávali adjuvantnú chemoterapiu, progresia ochorenia sa zistila u dvoch pacientov $(1,2 \%)$ s mediánom sledovania 56,2 mesiacov. Jeden pacient $(0,6 \%)$ zomrel 139,4 mesiacov po orchiektómii. Štatisticky významný rozdiel medzi oboma skupinami sa zistil v prežívaní bez progresie ochorenia, avšak nevýznamný bol rozdiel v celkovom preživaní.
This publication is the result of the implementation of project APVV-0016-11 supported by the Slovak Research and Development Agency.

Práca bola podporená grantom Agentúry pre podporu výskumu a vývoja APV - 0016-11.

The authors declare they have no potential conflicts of interest concerning drugs, products, or services used in the study.

Autoři deklarují, že $v$ souvislosti $s$ predmětem studie nemaji žádné komerční zájmy.

The Editorial Board declares that the manuscript met the ICMJE "uniform requirements" for biomedical papers.

Redakční rada potvrzuje, že rukopis práce splnil ICMJE kritéria pro publikace zasilané do biomedicínských časopisů.

prof. Dalibor Ondrus, MD, DSc. $1^{\text {st }}$ Department of Oncology Comenius University

Faculty of Medicine

St. Elisabeth Cancer Institute Heydukova 10

81250 Bratislava

Slovak Republic

e-mail: dalibor.ondrus@ousa.sk

Submitted/Obdrženo: 4. 3. 2015

Accepted/Prijiato: 8. 3. 2015

http://dx.doi.org/10.14735/amko2015112

Klúčové slová

testikulárne nádory - prísny dohl'ad - adjuvantná chemoterapia - progresia ochorenia 


\section{Introduction}

Testicular cancer is the most common cancer in males between 15 and 40 years. The introduction of cisplatin-based combination chemotherapy has revolutionized the treatment of metastatic testicular cancer [1]. Owing to high success rate in the salvage of disseminated cancer, it has become reasonable to propose for managing clinical stage I of nonseminomatous germ cell testicular tumors (CSI NSGCTT) patients with orchiectomy alone followed by surveillance only [2]. Patients who relapse are treated with systemic chemotherapy, whereas those who do not relapse are spared unnecessary treatment.

Surveillance after orchiectomy alone has gained a lot of popularity in the management of CSI NSGCTT. Preliminary results were enthusiastic [2-4], but critical voices have been raised against general use of this option as routine management [5]. With longer observation, relapse rate has been found to increase up to $25 \%$ or more after orchiectomy $[6,7]$. Several studies [5,7-9] identified statistically significant predictors of relapse in CSI NSGCTT patients who might therefore benefit from a program other than surveillance. Lymphovascular invasion (LVI) in the primary tumor was the most consistent prognostic feature identified. Predominantly embryonal carcinoma histology and T2-4 stage were also frequently associated with rate of relapse. The results of our previous reports [6,10-13] indicate that prognostic factors useful for stratification of CSI NSGCTT patients to different therapeutic approaches may be established. There have been identified risk factors which define a low-risk and a high-risk group of patients and have led to a risk-adapted approach of treatment favoring surveillance for patients with low-risk and chemotherapy for patients with high-risk of relapse [14,15].

The aim of contemporary study was to correlate own long-term experiences with active surveillance and adjuvant chemotherapy, resp. in CSI NSGCTT patients.

\section{Material and methods}

This cross-sectional longitudinal epidemiological study with prospective design was carried out in a single center which is focused on diagnosis and treatment of testicular cancer. The study began on January 31,1992 , by recruiting patients with newly diagnosed CSI NSGCTT from different regions of the Slovak Republic; last patient was included on August 31, 2014. The size of the total cohort, which consisted of all histological types of testicular tumors and was analyzed between 1993 and 2007 , represented $92 \%$ of all cases registered at the National Cancer Registry SR, i.e. the sample was representative. It is not possible to correlate the size of the whole study group (years 1992-2014) with the data from the NCR SR, due to insufficiency of published data from the NCR SR. However, we assumepersistence of representativeness. A total number of 454 newly diagnosed patients with CSI NSGCTT were followed until February 28, 2015, and their results were analyzed. At the time of patients' inclusion into the study, they were stratified according to selected risk factors (presence of LVI, majority of embryonal carcinoma components) for risk-adapted therapeutic approaches (surveillance and adjuvant chemotherapy, respectively). Minimal follow-up of these patients was six months.

The patients were assigned to their appropriate clinical stage on the basis of physical examination, CT of the chest abdomen and pelvis, postorchiectomy serum levels of tumor markers - alpha fetoprotein (AFP) and human chorionic gonadotropin ( $\beta$-hCG). The criteria for inclusion into CSI were normal values of all these examinations. Informed consent was obtained from all patients. Patients with choriocarcinoma component were not included in the study.

All performed diagnostic and therapeutical approaches were done according to actual guideline recommendations for patients with testicular cancer $[14,15]$, without intervention by reason of clinical trials; results of examinations and outcome were consecutively recorded and evaluated.

\section{Patients selection}

Group A consisted of 287 patients with LVI negative CSI NSGCTT, who were managed by the rules of surveillance, which consisted of a regular follow-up after orchiectomy with tumor markers (AFP, hCG) measurement and abdominal CT scans performed in 3-month-intervals in the first year, 6-month-intervals for the next 2-5years, and annually thereafter. Patients, who relapsed during follow-up, were treated with platinum-based combination chemotherapy - BEP regimen (bleomycin $30 \mathrm{U}$ IV on days 1,8 , and 15 plus etoposide $100 \mathrm{mg} / \mathrm{m}^{2}$ IV on days $1-5$ plus cisplatin $20 \mathrm{mg} / \mathrm{m}^{2}$ IV on days $1-5$; every 21 days).

Group B consisted of 167 patients with CS I NSGCT with LVI and/or > 50\% embryonal cell carcinoma in the orchiectomy specimen, who received two cycles of adjuvant BEP chemotherapy.

\section{Statistical analysis}

The age-specific characteristics of all patients were analyzed by using descriptive statistics. Data analysis was carried out in an R project setting. Normality of data distribution of age at the time of diagnosis in each study group was tested by Kolmogorov-Smirnov test. Continuous variables were compared by independent sample t-tests. Statistical significance of differences was tested according to the variables by Kruskal-Wallis test, chi-square test of independence and Wilcoxon test. Survival curves were generated using the Kaplan-Meier method, and they were compared by the Log Rank test. All statistical tests were two-sided and statistical significance was set at $p<0.05$.

\section{Results \\ Group A}

The mean age of 287 LVI negative CSI NSGCTT patients at the time of diagnosis was 30 (median 29.1 years, 25-75\% quantile was 24.4 and 34.2 years).

Relapse occurred in 48 (16.7\%) patients after a mean follow-up of 11.2 months (median 7.0 months, 25-75\% quantile was 5.15 and 12.5 months, range 2.1-86.1 months). Thirty-five patients (72.9\%) relapsed within the first year of follow-up, 18 patients (37.5\%) from them relapsed within six months after diagnosis.

Six patients (2.1\%) from this group died after a mean follow-up of 42.8 months (median 34.3 months, range 11.4 to 179.7 months). Progression-free survival (PFS) was $83.3 \%$ with a median follow-up of 113.9 months. Overall survival (OS) rate of CSI NSGCTT patients in 


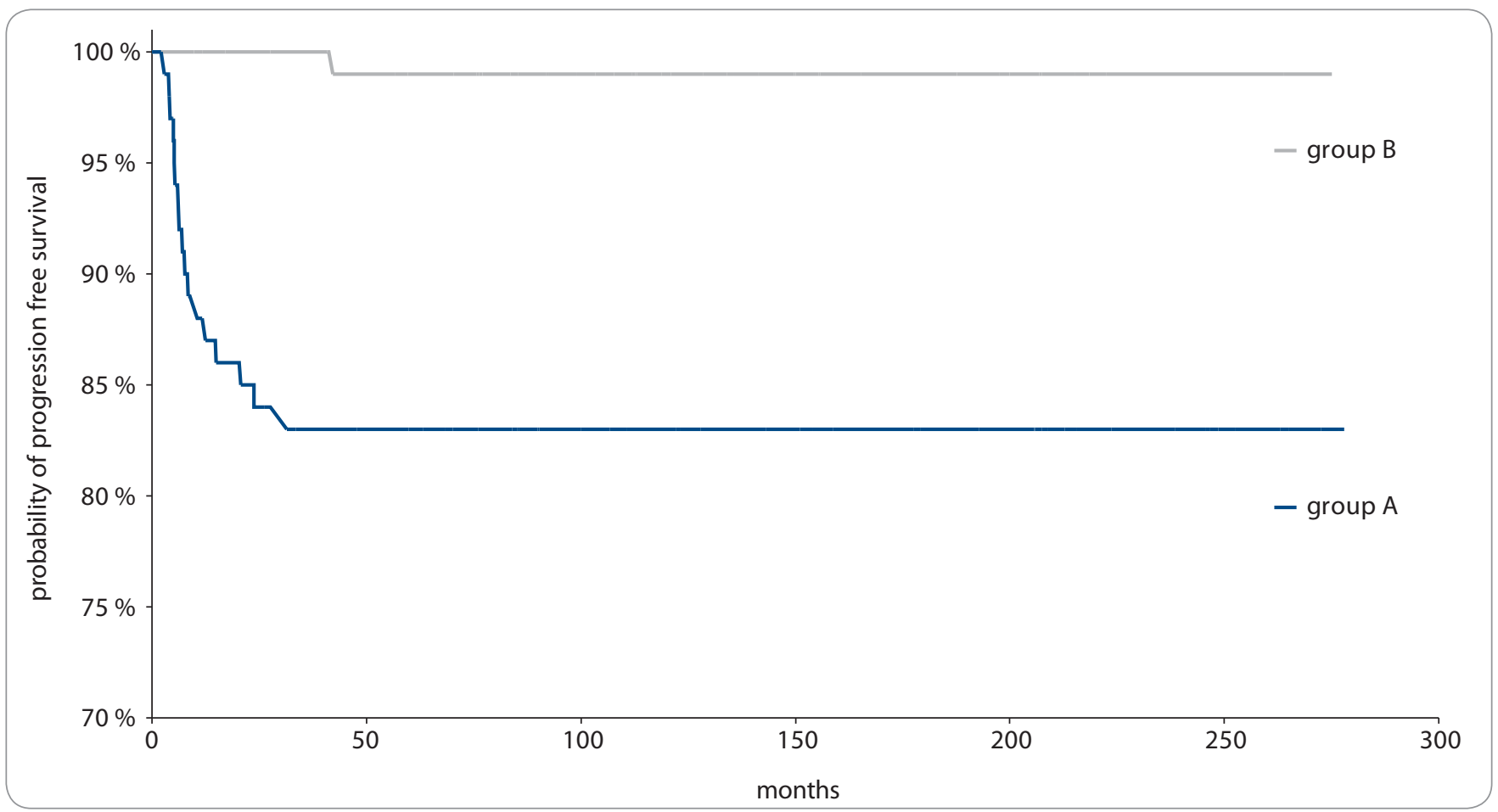

Graph 1. Probabillity of progression free survival in patients who underwent surveillance (group A) and patients who underwent adjuvant chemotherapy (group B).

group A was 281/287 (97.9\%) with median follow-up of 142 months (mean 148.1 months) following orchiectomy.

\section{Group B}

The mean age of 167 patients with LVI positive CSI NSGCTT was 31.2 (median 30.1 years, $25-75 \%$ quantile was 24.7 and 35.9 years).

Relapse was recorded in two (1.2\%) patients after a mean time of 56.2 months (42.2 and 49.4 months). One of them (0.6\%) died 139.4 months after primary treatment. PFS was $98.8 \%$ with a median follow-up of 134 months. OS rate of CSI NSGCTT patients in group B was $166 / 167$ (99.4\%) with median follow-up of 135.7 months (mean 120.3 months).

Comparing these two groups of patients, statistically significant difference in proportion of patients without progression (83.3\% vs. $98.8 \%)$ was found ( $p<0.001$ ) (Graph 1) with no significant difference in the median of progression free follow-up. No significant difference in OS was recorded.

\section{Discussion}

Over the last 35 years, the distribution of stage in initial diagnosis of NSGCTT has changed, with more patients being diagnosed at earlier stages. Approximately $30-50 \%$ of patients with NSGCTT present with CSI disease $[15,16]$.

The management of CSI NSGCTT following orchiectomy is controversial and generates the most debate. Options include surveillance (with salvage treatment for relapse), adjuvant cisplatin-based combination chemotherapy, or retroperitoneal lymph node dissection (RPLND). All options provide cure rates of approximately $99 \%$ [17]. In the USA a standard postorchiectomy approach has been nerve-sparing RPLND, while mainly in Europe, primary surgical approaches have fallen out of favor and nonsurgical approaches now predominate. Recent guidelines of the European Germ Cell Cancer Consensus Group (EGCCCG) [14] recommend active surveillance for low-risk CSI NSGCTT patients and adjuvant chemotherapy with two cycles of BEP for high-risk CSI NSGCTT.

Since only $30 \%$ of patients relapse during surveillance, $70 \%$ of patients who are cured by orchiectomy alone could be unnecessary exposed to adjuvant treatment-related toxicity. To reduce this overtreatment, the EAU 2009 guideli- nes [18] advise a 'risk-adapted treatment approach' recommending adjuvant treatment only for high-risk cases. The EAU 2009 guidelines [18] propose two cycles of adjuvant BEP chemotherapy to those high-risk patients with pT2NOMO (LVI positive) or pT3-4NOM0, while those low-risk cases (pT1N0M0, LVI negative) are recommended to undergo surveillance.

Given that all current strategies for CSI NSGCTT, when carried out well, lead to nearly uniform cure, diminishing treatment-related morbidity has become the primary concern.

Few large European or USA series of non-risk adapted treatment utilizing primary active surveillance for all patients with CSI NSGCTT irrespective to risk profile have been reported [19-21]. There were $221 / 1,139$ (19\%) relapses with median follow-up of 62 months described in the recent Kollmansberger et al [19] study with median time to relapse 6.0 months. Canadian study [20] using non-risk-adapted approach described two cohorts. In the initial cohort (1981-1992), $53 / 157$ (33.8\%) relapsed compared with $51 / 214(23.8 \%)$ in the recent cohort (1993-2005). In our previous study [13], there were $52 / 145$ (35.9\%) relapses fol- 
lowing surveillance only with a median follow-up of 6.5 months. Non-risk-adapted surveillance provides excellent survival and reduces the overall treatment burden and potentially the longer-term toxicities of treatment [20]. Nichols et al [21] argue that adjuvant chemotherapy results in unnecessary treatment for approximately $50 \%$ of these patients with increasing awareness of the long-term risk for cardiovascular diseases and second malignancies attributable to platinum-based chemotherapy. On the other hand, based on the historical literature, active surveillance of all patients with CSI NSGCTT, i.e. without risk stratification, will result in delayed treatment of relapse in up to $30 \%$ of patients, usually with multiple cycles of chemotherapy and surgical resection of residual masses [22].

The European current guidelines $[14,15]$ recommend risk-adapted approach in CSI NSGCTT. The results of large prospective SWENOTECA study [23] showed LVI negative patients who chose surveillance relapse rate 39/228(13.5\%) at a median follow-up of 5.0 years. In our present prospective study, we observed the relapse rate $48 / 287(16.7 \%)$ at a median follow-up of 7.0 months. Recent results of the SWENOTECA study [24] showed 258 LVI positive patients (follow-up 8.0 years) receiving one course of BEP $8(3.2 \%)$ relapse with median time to relapse 1.1 years. Albers et al [25] reported results of the largest randomized trial (German Testicular Cancer Study Group) investigating adjuvant treatment strategies in CSI NSGCTT which showed $2 / 174(1.2 \%)$ relapses following one course of BEP chemotherapy. In our present cross-sectional longitudinal study, we observed LVI positive patients receiving two courses of BEP regimen $2 / 167(1.2 \%)$ relapses at a median follow-up of 56.2 months. Administration of adjuvant chemotherapy after orchiectomy on CSI NSGCTT nearly eliminates the risk of relapse. A pooled analysis of 13 studies involving 1,043 patients revealed a relapse rate of $1.6 \%$ with six patients $(0.6 \%)$ dying of disease [26]. Given the two cycles of BEP, only $3 \%$ of patients relapsed; therefore, the risk reduction of relapse is $90 \%$. According to EGCCCG in Europe, two cycles of BEP chemotherapy are considered the standard treatment option $[14,27,28]$. Considering very similar outcomes of active surveillance and adjuvant chemotherapy (OS), individual patient preferences should be a strong factor in management decision [29].

\section{Conclusions}

Our recent experience confirms that surveillance policy is recommended only in low-risk CSI NSGCTT patients (LVI negative). Patients at high risk of relapse (LVI positive) may be cured with adjuvant chemotherapy. Further studies with long-term follow-up are necessary, they will give answer for controversies between non-risk-adapted and risk-adapted treatment approach in the future.

\section{References}

1. Einhorn LH, Donohue J. Cis-diamminedichloroplati num, vinblastine, and bleomycin combination chemo therapy in disseminated testicular cancer. Ann Intern Med 1977; 87(3): 293-298

2. Peckham MJ, Barrett A, Husband JE et al. Orchidectomy alone in testicular stage I nonseminomatous germ cell tumors. Lancet 1982; 2(8300): 678-680.

3. Johnson DE, Lo RK, von Eschenbach AC et al. Surveillance alone for patients with clinical stage I nonseminomatous germ cell tumors of the testis: preliminary report. J Urol 1984: 131(3): 491-493.

4. Sogani P, Whitmore WF, Herr HW et al. Orchiectomy alone in the treatment of clinical stage I nonseminomatous germ cell tumor of the testis. J Clin Oncol 1984; 2(4): 267-270

5. Thompson PI, Nixon J, Harvey VJ. Disease relapse in patients with stage I nonseminomatous germ cell tumor of the testis on active surveillance. J Clin Oncol 1988; 6(10): 1597-1603.

6. Ondrus D, Hornak M. Orchiectomy alone for clinical stage nonseminomatous germ cell tumors of the testis (NSGCTT): a minimum follow-up period of 5 years. Tumori 1994; 80(5): 362-364

7. Sturgeon JF, Jewett MA, Alison RE et al. Surveillance after orchiectomy for patients with clinical stage I nonseminomatous testis tumors. J Clin Oncol 1992; 10(4): 564-568.

8. Klepp O, Olsson AM, Henrikson H et al. Prognostic fac tors in clinical stage I nonseminomatous germ cell tumors of the testis: multivariate analysis of a prospective multicenter study. J Clin Oncol 1990; 8(3): 509-518. 9. Wishnow KI, Johnson DE, Swanson, DA et al. Identifying patients with low risk clinical stage nonseminomatous testicular tumors who should be treated by surveillance. Urology 1989: 34(6): 339-343.

10. Ondrus D, Hornak M, Vrabec J. Low sperm counts as a prognostic factor of progression in stage I non-seminomatous germ cell testicular tumours. Br J Urol 1988; 62(2): 82-84.

11. Ondrus D, Gonçalves F, Kausitz J et al. The value of prognostic factors in the management of stage I nonseminomatous germ cell testicular tumors (NSGCTT). Neoplasma 1996: 43(3): 195-197.

12. Ondrus D, Matoska J, Belan V et al. Prognostic factors in clinical stage I nonseminomatous germ cell testicula tumors: rationale for different risk-adapted treatment. Eu Urol 1998; 33(6): 562-566
13. Ondrus D, Ondrusova M, Hornak M et al. Nonseminomatous germ cell testicular tumors - clinical stage I: differentiated therapeutic approach in comparison with therapeutic approach using surveillance strategy only. Neoplasma 2007; 54(5): 437-442.

14. Krege S, Beyer J, Souchon R et al. European consensus conference on diagnosis and treatment of germ cell cancer: a report of the second meeting of the European Germ Cell Cancer Consensus group (EGCCCG): part I. Eur Urol 2008; 53(3): 478-496.

15. Albers $P$, Albrecht $W$, Algaba F et al. EAU guidelines on testicular cancer: 2011 update. Eur Urol 2011; 60(2): 304-319. doi: 10.1016/j.eururo.2011.05.038.

16. Coleman S, Stephenson A. Controversies in the management of stage I non-seminomatous germ cell tumors. Curr Urol Rep 2013; 14(5): 506-510. doi: 10.1007/s11934-013-0362-5.

17. Albers P, Siener, R, Kliesch S et al. Risk factors for relapse in clinical stage I nonseminomatous testicular germ cell tumors: results of the German Testicular Cancer Study Group Trial. J Clin Oncol 2003; 21(8): 1505-1512.

18. Brewster SF. Challenging the EAU 2009 guidelines on testis cancer: the risk-adapted management of stage I nonseminomatous germ cell tumours: surveillance yields equal results with less toxicity. Eur Urol 2010; 1 (Suppl): 459-461.

19. Kollmansberger $\mathrm{CH}$, Tandstad T, Bedard, PL et al. Patterns of relapse in patients with clinical stage I testicular cancer managed with active surveillance. J Clin Oncol 2015: 33(1): 51-57. doi: 10.1200/JCO.2014.56.2116.

20. Sturgeon JF, Moore MJ, Kakiashvili DM et al. Non-risk-adapted surveillance in clinical stage I nonseminomatous germ cell tumors: the Princess Margaret Hospital's experience. Eur Urol 2011; 59(4) 556-562. doi: 10.1016/j.eururo.2010.12.010. 21. Nichols CR, Roth B, Albers $P$ et al. Active surveillance is the prefered approach to clinical stage I testicular cancer. J Clin Oncol 2013; 31(28): 3490-3493. doi: 10.1200/JCO.2012.47.6010.

22. Jewett MAS, Richie JP, Albers P. Treatment of nonseminoma: Stage I. In: Laguna MP, Albers P, Bokemeyer C, Richie JP (eds). Cancer of the testis. London: Springer Verlag 2010: 147-166.

23. Tandstad T, Dahl O, Cohn-Cedermark G et al. Risk-adapted treatment in clinical stage I nonseminomatous germ cell testicular cancer: The SWENOTECA management program. J Clin Oncol 2009; 27(13): 2122-2128. doi: 10.1200/JCO.2008.18.8953

24. Tandstad T, Ståhl O, Håkansson U et al. One course of adjuvant BEP in clinical stage I nonseminoma mature and expanded results from the SWENOTECA group. Ann Oncol 2014: 25(11): 2167-2172. doi: 10.1093/annonc/mdu375. 25. Albers P, Siener R, Krege S et al. Randomized phase III trial comparing retroperitoneal lymph node dissection with one course of bleomycin and etoposide plus cisplatin chemotherapy in the adjuvant treatment of clinical stage I nonseminomatous testicular germ cell tumors: AUO trial AH 01/94 by the German Testicular Cancer Study Group. J Clin Oncol 2008; 26(18): 2966-2972. doi: 10.1200/JCO.2007.12.0899

26. Westermann DH, Studer UE. High-risk clinical stage I nonseminomatous germ cell tumors: the case for chemotherapy. World J Urol 2009; 27(4): 455-461. doi: 10.1007/s00345-009-0456-3.

27. Abrahamova J. Therapeutic approaches for early stage nonseminomatous germ cell testicular tumors. Klin Onkol 2008; 21(3): 81-85

28. Lakomy R, Poprach A, Nemecek R et al. Adjuvant treatment for stage I of testicular germ cell tumours. Klin Onkol 2009; 22(1): 22-26.

29. Oldenburg J, Aparicio J, Beyer J et al. Personalizing, not patronizing: the case for patient autonomy by unbiased presentation of management options in stage I testicular cancer. Ann Oncol (2014). doi: 10.1093/annonc/mdu514. First published online: November 6, 2014. 